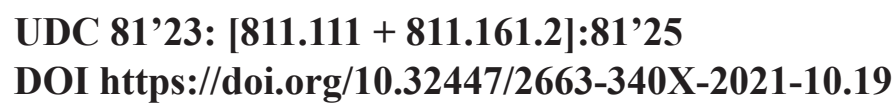

\title{
THE TRANSLATING PECULIARITIES OF ENGLISH PUBLICIST TEXTS INTO THE UKRAINIAN LANGUAGE
}

\author{
Ruda Anastasiia Volodymyrivna \\ Senior Lecturer at the Department of "Philology", \\ State Institution "Odessa National Maritime University" \\ 34, Mechnykov Str., Odesa, Ukraine
}

\begin{abstract}
In the focus of the research, there are peculiarities of translating English publicist texts into the Ukrainian language. The issue is investigated in the paradigm of genre specificity of publicist texts. The challenges resulting from the typological discrepancy of the source language (English) and the target language (Ukrainian)both on the lexical and grammatical levels are also considered. The objective is to distinguish the peculiarities of rendering publicist texts from English into Ukrainian regarding the distinctive features of the publicist style. According to the results of the analysis of the peculiarities of rendering English publicist texts in Ukrainian aimed at defining dominant translation strategies, tactics and operations, the two prominent translation strategies are the strategies of communicatively relevant translation and readdressing. As for the translation tactics, the most recurrent there prove to be the tactic of relevant information rendering, the tactic of correct information presentation, and the tactic of linguistic and cultural adaptation. The most widely spread translation transformations are transcription, transliteration, loan translation, concretization, generalization, and semantic development. The wide distribution of transcription and transliteration is due to the high occurrence of geographical and personal proper names. The extensive employment of concretization results from the discrepancy in the vocabulary of the typologically distant languages. As for the peculiarities of rendering phraseological units in publicist texts the main translation transformations employed are semantic, lexical, syntactic, morphological, and word-building transformations. This results in the use of reduction, contamination, attachment, parcelling, omission, ellipsis, and various replacements. The perspective is seen in investigating the peculiarities of translating scientific texts from English into Ukrainian.

Key words: publicist texts, publicist style, peculiarities, translation strategy, translation tactics, translation operations.
\end{abstract}

Problem-setting and groundings for its urgency. The article dwells upon the peculiarities of rendering publicist texts from English into Ukrainian considering the specificity of publicist style. Publicist texts are defined as informational texts, employed in newspapers, periodicals, magazines and other mass media. Publicist style was formed based on belles-lettres, scientificpopular and official styles, thus possessing some of their peculiarities. In our interpretation publicist style is the style of social communication, aimed at highlighting urgent issues and challenges, thus combining high semantic density and pragmatic variability. Still, the prominent feature of the publicist style is its potential adaptability to the changes in social life and its high manipulative capability. Publicist style is in a certain way an interim field of artistic, scientific and business communication, thus combining partially their functions, linguistic and stylistic peculiarities. The main spheres of publicistic style application are social-cultural, political, industrial and educational.

Its main mission is to facilitate the solution of urgent social issues and challenges, motivate the target audience for active social position and creativity, distribute knowledge, democratic, environmental, and socially relevant ideas, healthy food and lifestyle. The functional aspects of the publicist style have greatly influenced its distinctive features formation: logicality and emotivity, assessment-social-political, ideological, aesthetic, moral, biasness in rendering facts, synthesis of the objectivity and imaginativity, rationality and expressiveness.

Recent research analysis. The history of the publicist style research dates back to the works of such well-known scholars as G. Rukalova, V. Komissarov, I. Alekseeva etc. Publicist texts are defined as coherent, verbally expressed texts (either in written or oral form), viewed in their relationship with various determining factors (pragmatic, sociocultural, mental, social) and their functional aspect. The main functions of commercial publicist texts are informative and manipulative.

The genre variety of publicist texts has been investigated in the works by $O$. Halych [3], D. Hryhorash [4], O. Hryshchenko [5], V. Zdoroveha [6], L. Kroychyk [8], M.Podolyan [10], O.Tertychnyi [12] etc. The main achievement of these works is in the attempt to differentiate publicist texts from other 
genres. The novelty of our research consists in the focus upon the peculiarities of the publicist texts viewed in translational aspects.

The objective and tasks. The objective of the research is to distinguish the peculiarities of rendering publicist texts from English into Ukrainian considering the specificity of publicist style. The tasks are as follows:

- to systematize the existing approaches to the understanding and classification of publicist texts;

- to define the distinctive features of publicist texts in general;

- to outline the prevailing language means in the publicist texts;

- to distinguish the dominant translation operations employed in rendering English publicist texts in Ukrainian.

The findings of the research. If analyzed as a genre publicist texts are defined as coherent speech products containing the following mandatory components: a) data about the facts, news or challenges; b) fragmentary or substantial grounding of the situation in the focus; c) devices of the emotional influence upon the target audience $[8,138]$. In this connection there are differentiated the following five publicist texts genre subtypes: 1) news; 2) interviews; 3) comments; 4) reviews; 5) essays or pamphlets.

The distinctive features of publicist texts, in general, are the following:

- the accessibility of language means;

- the combination of logical and polemical aspects in semantics;

- the combination of factual, emotive, and aesthetic information;

- the employment of the vivid expressive means of the explicit author's message;

- the wide distribution of stylistic devices.

The prevailing language means in the publicist texts include:

- the synthesis of the elements of belles-lettres, scientific-popular and colloquial styles;

- the high density of common and specific terms and professional words;

- the high expressiveness of the narrative;

- the occurrence of words with figurative meaning;

- the wide distribution of words with foreign affixes like -ist, -ator, - ation, pseudo-, neo-, super-, inter- etc;

- the employment of different kinds of interrogative, exclamatory, and imperative sentences, inversion, complex and compound sentences with various subordinate clauses;

- the speaking titles and headings with transparent inner forms.
Other distinctive features of publicist texts are respectively as follows: orientation at novelty; dynamism; high information density; explicit attitude to the described phenomena in political, social and ethical aspects; appeal; the combination of standard norms and expressive varieties; subjectivity; high persuasive capability. As for the language means and stylistic devices employed they form a unique amalgam of the constituents of official, scientific-popular and belles-lettres styles. From one side, it's characterized by the wide distribution of social and political vocabulary, appeals, slogans, proper geographical names, dates, on the other side there is a variety of expressive means employed, including tropes and lexicosyntactic devices. All lexemes are charged with positive or negative evaluative connotations. The author's narrative coincides with the protagonist's monologue. There are registered the prevalence of lexis of different professional fields like economy, legislation, culture, education, science. The general register is rather literary than colloquial, expressive than neutral.

It is first and foremost in translating publicist texts to adequately interpret the sense, pragmatics and expressiveness, also considering the specificity of terminology.

According to I. Alekseeva [1], V. Komissarov [7], and L. Latyshev [9], translation is a process of transforming the content of a speech fragment from one language into another. Translation transformations are basic translation operations consisting of the interlinguistic reconstruction of the meaning of the elements of the source text by linguistic means of another language. Such operations may be treated as interlinguistic periphrasis or reformulation.

In the course of the research, it has been concluded that lexical translation transformations are employed in cases when there occur unique, culturally biased lexical units like proper names, both geographical and personal ones, specific terms and professional words peculiar for certain fields of knowledge. All these objects and phenomena are identified as typical of particular culture or nationality.

According to the findings of the research, the most recurrent lexical translation transformations are transcription, transliteration, loan translation, concretization, generalization, and semantic development.

One of the challenges in translating publicist texts is rendering headings. The translation of headings should be performed on the final stage of the perception of the source text. Another distinctive feature of English headings is the 
ambiguity of meaning sometimes based upon the transfer of meaning or play on words. Graphons are also often employed as powerful means of paronymical attraction. Subtitles and captions often are very helpful when it comes to deciphering publicist texts.

Among the grammatical and lexical discrepancies between the source language (English) and the target language (Ukrainian) there are as follows:

- the prevalence of present tense verb forms in English in the retrospective meaning, like 'Mary Grace dies', 'Royal family quits'. Past Simple tense form is used in English newspaper headings only in case of simultaneous employment of adverbial modifiers of time referring to the past and the infinitive is used in reference to the future;

- idiomaticity revealed in the wide distribution of phraseological units.

Many phraseological units contain metaphorical or metonymical elements or are nationally or culturally biased. These peculiarities search for equivalents and analogues challenging. The challenge consists in the necessity of comprehending the essence of idioms before rendering it in another language.

The main ways of translating phraseological units from English into Ukrainian are as follows:

- to choose an appropriate phraseological unit, either a full equivalent or a partial correspondence;

- to apply semantic translation based on analogy by adducing phraseological units with the same meaning but different images;

- to translate by word-for-word translation thus coining a new phraseological unit;

- to employ descriptive translation.

It should be borne in mind that in such case the following requirements should be met:

The image should be motivated, with the transparent inner form.

If there are any realia their meaning should be derived from the context.

The translated phraseological unit should be structured as a phrase.

It should be remarked that phraseology is widely used in publicist texts. It adds up to the degree of expressiveness and vividness of images.

Translating phraseological units adequately is always challenging and it requires extensive background knowledge and excellent linguistic competence.

Two reverse in direction translation transformations in rendering phraseological units are respectively the deformation and contamination of phraseology. The deformation consists of the changes in the syntactic structure of phraseological units, while contamination lies in their extension or replacement of constituents with other lexical units ruining the idiomaticity.
Among other difficulties of publicist style in the translational aspects, there is a mixture of functional styles revealed in the simultaneous employment of literary style elements and colloquial words in one context.

The most objective and emotively neutral in the register there are articles and news reports if compared with interviews, essays and reviews.

We adhere to the following classification of the translation transformations employed in rendering phraseological units in publicist texts:

1) semantic transformations;

2) lexical transformations;

3) syntactic transformations;

4) morphological transformations;

5) word-building transformations.

Semantic transformations consist in providing a new meaning for phraseological units without any changes in their lexico-grammatic integrity. The so-called dephraseologicalization is defined as the loss of the idiomaticity of a phraseological unit due to the acquisition of new meanings by its lexical components. This is a very powerful and vivid expressive means with a strong pragmatic effect. This may be illustrated by the following example: "Carol has always been a black sheep in the class: her parents were Afro-Americans". The most apt translation would be: «Керол стала в класі білою вороною, бо іiі батьки були афроамериканцями». It is worth summing up that the crucial factor in such semantic transformations in the context.

Unlike semantic transformation, lexical transformations take place when there occur changes in the lexical semantics of the initial phraseological unit without any changes in the structure of the utterance. This may be illustrated by replacement and transposition. "The rapid global economic downturn has rekindled fears that Japan may be slipping back into a deflationary cycle". In the phraseological unit "to kindle the flame" "kindle" is substituted for "rekindle" and "the flame" is replaced by "fears".

However, the most prevailing there are still syntactic transformations, according to which the syntactic structure of a phraseological unit is shortened, prolonged or transformed. Such transformations include a reduction (ellipsis); attachmentoraddition; changes in the communicative type; parcelling; contamination; allusion.

Reduction is interpreted as the shortening of a phraseological unit structure, omission of its relevant elements. Mostly there are omitted verbs that function chiefly as syntactic nuclei and don't contribute to the general lexical meaning as much as nominative constituents. For example: "There is one silver lining for Sadler: the injury does not appear to be career-threatening". In the source 
phraseological unit, there is another wording "Every cloud has a silver lining".

Ellipsis presupposes the omission of the initial or final structural elements of a phraseological unit resulting in its semantic infinity like "There's as good fish in the sea as ever came out of it" is often rendered in newspapers as "There's as good fish in the sea". Attachment or addition may occur in any part of a phraseological unit - initial, medial or final. This is often combined with the complex lexico-grammatical transformation of semantic development. Such changes may produce an unexpected effect and are more typical of headings. Like in the following example: "Tourism is a goose that not only lays a golden egg but also fouls its own nest. We come up against an emotional blank wall, a dead-end".

Parcelling is a specific transformation of phraseological units, consisting in separating parts of the utterance by punctuation marks, mostly commas, occasionally full stops. This is often employed to attract more attention and foreground some elements. Like in the example: "They welcomed the law. With open arms".

Contamination is understood as a stylistic device semantically and syntactically uniting two or more phraseological units due to telescoping or blending loke: "There is enough of a consensus that they have begun to tackle the next steps". In this case, there is the contamination of two English phraseological units: "to tackle a problem" and "to take steps".

An allusion is defined as a reference to some well-known fact, historical event, literary work. This device is based upon the semantic interrelation of the conventional and modified phraseological units achieved due to the preserved semantics of the conventional unit. This device is very powerful but may remain implicit if the translator doesn't possess the required competence and skills.

Morphological transformations consist of the changes in the grammatical aspect in phraseological units. Occasional morphological replacements involve changes in lexico-grammatical meaning thus transforming the semantics. This is relevant for the modification of articles, nouns, degrees of comparison of adjectives, tense verb forms. Like: "Baseball might be as American as apple pie, but the gold medal hopes of the US team proved to be pies in the sky on Friday night".

The conclusions and perspective. According to the results of the analysis of the peculiarities of rendering English publicist texts in Ukrainian aimed at defining dominant translation strategies, tactics and operations, the two prominent translation strategies are the strategies of communicatively relevant translation and readdressing. As for the translation tactics, the most recurrent there prove to be the tactic of relevant information rendering, the tactic of correct information presentation, and the tactic of linguistic and cultural adaptation.

As far as translation transformations are concerned, themostextensivetherearetranscription, transliteration, loan translation, concretization, generalization, and semantic development. The most widely spread is transcription, $43 \%$, which is due to the high occurrence of geographical and personal proper names. Concretization and generalization take up respectively $19 \%$ and $18 \%$, which is due to the discrepancy in the vocabulary of the typologically distant languages.

The choice of loan translation, transliteration or mixed-method is often set by the dictionary, but there are many cases, especially those related to historical and cultural names, rare geographical names, new terms, which require an independent decision of the translator. Here are some considerations that can help formulate a translator's attitude: firstly, the choice in favour of the accuracy (literality) of the translation is not always the most successful, since as a result, a word that is too inconvenient to be perceived is created - this often happens with word-for-word.

Secondly, loan translation often becomes a better way of translation than transcription, since as a result of transcriptions, inappropriate words are coined and, much worse, words that do not make sense in the target language. If the transcription cannot be avoided at all, then it is usually combined with the loan translation, which is often found when translating nicknames or talking names. A specific complication when using this method is the need to deploy or collapse the source structure, that is, to add additional elements or abbreviate the original elements.

In general, it can be stated that the choice of one or another possibility of transferring proper names that have retained a certain semantics, that is, the choice of transliteration or translation, is due to a tradition with which translators cannot but reckon when coming across the names of historical personalities or fictional characters, although here the fluctuations are much frequent. As for their names that do not have their semantics in the modern language, the question of transfer naturally does not get up, and the analogy with the forms of reality transfer stops here.

As for translating phraseological units in publicist texts the main translation transformations employed are semantic, lexical, syntactic, morphological, and word-building transformations. This results in the use of reduction, contamination, attachment, parcelling, omission, ellipsis, and various replacements. The perspective is seen in investigating the peculiarities of translating scientific texts. 


\title{
BIBLIOGRAPHY
}

1. Алексеева И.С. Текст и перевод. Вопросы теории. Москва: Междунар. отношения, 2008. 184 с.

2. Вагапова Л. Л. Прагматический аспект перевода. Москва: Самиздат, 2008. 74 с.

3. Галич О. Теорія літератури. Київ: Либідь, 2001. 488 с.

4. Григораш Д. Журналістика у термінах і виразах. Львів:Вища школа, 1974. 296 с.

5. Грищенко О. Основи теорії журналістської діяльності. Київ: Міжнар. Інститут лінгвістики і права, 2000. 205 с.

6. Здоровега В. Теорія і методика журналістської творчості. Львів: ПАІС, 2004. 268 с.

7. Комиссаров В.Н. Теория перевода (лингвистические аспекты). Москва: Альянс, 2013. 253 с.

8. Кройчик Л. Система журналистских жанров. Санкт-Петербург: Знание, 2000. С. 125-167.

9. Латышев Л.К., Семенов А.Л. Перевод: теория, практика и методика преподавания. Москва: Академия, 2008.192 с.

10. Подолян М. Публіцистика як система жанрів. Київ: Київський ун-т, Інститут журналістики, Центр вільної преси, 1998. 48 с.

11. Різун В. Літературне редагування. Київ: Либідь, 1996. 234 с.

12. Тертычный А. Жанры периодической печати. Москва: Аспект Пресс, 2000. 312 с.

\section{REFERENCES}

1. Alekseeva, I.S. (2008). Tekst i perevod. Voprosy teoriyi. [Text and translation. Theoretical issues]. Moskva: Mezhdunar. otnoshenyia. [in Russian].

2. Vahapova, L.L. (2008). Prahmaticheskiy aspekt perevoda. [The pragmatic aspect of translation]. Moskva: Samyzdat. [in Russian].

3. Halych, O. (2001). Teoriia literatury. [Literature theory]. Kyiv: Lybid. [in Ukrainian].

4. Hryhorash, D. (1974). Zhurnalistyka u terminakh i vyrazakh. [Journalism in terms and expressions]. Lviv:Vyshcha shkola. [in Ukrainian].

5. Hryshchenko, O. (2000). Osnovy teoriyi zhurnalistskoi diyalnosti. [The fundamentals of the theory of journalistic activity]. Kyiv: Mizhnar. Instytut linhvistyky i prava. [in Ukrainian].

6. Zdoroveha, V. (2004). Teoriya i metodyka zhurnalistskoi tvorchosti. [The theory and methodology of journalistic creativity]. Lviv: PAIS. [in Ukrainian].

7. Komissarov, V.N. (2013). Teoriya perevoda (lingvisticheskiye aspekty). [Translation theory (linguistic aspects)]. Moskva: Alians/ [in Russian].

8. Kroichyk, L. (2000). Sistema zhurnalistskikh zhanrov. Saint Petersburg: Znaniye. [in Russian].

9. Latyshev, L. K., Semenov, A. L. (2008). Perevod: teoriya, praktika i metodika prepodavaniya. [Translation: theory, practice and methodology of teaching]. Moskva: Akademyia. [in Russian].

10. Podolian, M. (1998). Publitsystyka yak systema zhanriv. [Journalism as the system of genres]. Kyiv: Kyivskyi un-t, Instytut zhurnalistyky, Tsentr vilnoi presy. [in Ukrainian].

11. Rizun, V. (1996). Literaturne redahuvannia. [Literary editing]. Kyiv: Lybid. [in Ukrainian].

12. Tertychnyi, A. (2000). Zhanry periodicheskoi pechati. [Genres of periodicals]. Moskva: Aspekt Press. [in Russian].

\section{ОСОБЛИВОСТІ ПЕРЕКЛАДУ АНГЛІЙСЬКИХ ПУБЛІЦИСТИЧНИХ ТЕКСТІВ УКРАЇНСЬКОЮ МОВОЮ}

\author{
Руда Анастасія Володимирівна \\ старший викладач кафедри «Філологія» \\ Державного закладу «Одеський національний морський університет» \\ вул. Мечникова, 34, Одеса, Україна
}

\begin{abstract}
Дослідження присвячене особливостям перекладу англійських публіцистичних текстів украӥнською мовою. Це питання досліджується у парадигмі жанрової специифіки публічистичних текстів. До уваги приймаються також труднощі, спричинені типологічними відмінностями між вихідною мовою (англійською) та иільовою мовою (українською) на лексичному та граматичному рівнях. Мета дослідження у визначенні особливостей відтворення англійських публічистичних текстів украӥнською мовою з урахуванням провідних характеристик публіичистичного стилю. Згідно результатам аналізу особливостей перекладу англійських публіцистичних текстів украӥнською мовою, спрямованому на визначення провідних перекладацьких стратегій, тактик і операцій, двома провідними стратегіями перекладу є стратегія комунікативно рівноцінного перекладу і стратегія переадресаиії. Щодо тактик перекладу, найбільш частотними виявились тактика передачі релевантної інформації, тактика коректного оформлення інформаџіï та тактика лінгвокультурної адаптації. Найбільш розповсюдженими перекладацькими трансформаціями є транскрипція, транслітерація, калькування, конкретизаџія, генералізація та прийом семантичного розвитку. Поширеність транскрипції та транслітерації спричинена розповсюдженістю власних назв, топонімів і антропонімів. Широке використання конкретизаиії пов'язане з типологічними відмінностями у вокабулярі неспоріднених мов. Щодо особливостей відтворення фразеологічних одиниць у публіичстичних текстах провідними перекладацькими трансформаціями є семантичні, лексичні, синтаксичні, морфологічні та словотвірні трансформації. Це спричинює застосування редукиї, контамінації, додавання, париелячії, вилучення, еліпсису та різних видів замін. Перспектива вбачається у дослідженні особливостей перекладу наукових текстів з англійської мови украӥнською.
\end{abstract}

Ключові слова: публіцистичні тексти, публіцистичний стиль, особливості, перекладацька стратегія, перекладацькі тактики, перекладацькі операції. 